\title{
ANALYSIS OF FORCED DRAFT COOLING TOWER PERFORMANCE USING ANSYS FLUENT SOFTWARE
}

\author{
S. Parimala Murugaveni ${ }^{1}$, P. Mohamed Shameer ${ }^{2}$ \\ ${ }^{I}$ Asisstant Professor (Senior Grade), Department of Mechanical Engineering, Government College of Technology- \\ Coimbatore, Tamilnadu, India \\ ${ }^{2} P G$ student (Thermal Engineering), Department of Mechanical Engineering, Government College of Technology- \\ Coimbatore, Tamilnadu, India
}

\begin{abstract}
In this project the cooling tower performance has been analyzed by varying air inlet parameters with different air inlet angles and by attaching a nozzle in air inlet. The cooling tower analyzed here is used specifically for small scale industries, which is forced draft counter-flow cooling tower with single module capacities from 10 to 100 cooling tons. In this project 50 tons cooling capacity model has been taken as reference model. The analysis has been done using computational fluid dynamics (CFD) ANSYS 14.5 software. The cooling tower models have been modeled using SOLIDWORKS 2013 software and they have been meshed using ICEM CFD 14.5 software. The meshed models have been analyzed using FLUENT software. The air inlet angles varied in horizontal direction, vertical direction and by combining both horizontal and vertical inclination. A convergent nozzle has been modeled and assembled to the inlet pipe. The temperature contours of the cooling tower models have been taken from the analysis. Based on the outlet cold water temperature, the improved effectiveness of the cooling tower model has been obtained.
\end{abstract}

Keywords: Forced draft cooling tower, Air inlet parameter, Convergent nozzle, Cooling ton capacity, Counter flow cooling tower, Ansys 14.5, Solidworks 2013, ICEM CFD 14.5, Effectiveness of cooling tower.

\section{INTRODUCTION}

A cooling tower is a type of heat exchanger used to reduce the temperature of a water stream by extracting heat from water and emitting it to the atmosphere. Cooling towers use the evaporation of water to remove process heat and cool the working fluid to near the wet-bulb air temperature. Cooling towers are able to lower the water temperatures more than devices that use only air to reject heat, like the radiator in a car, and are therefore more cost-effective and energy efficient. They are generally used in HVAC application. There are many types of cooling tower available. The forced draft cross flow and counter flow cooling tower are the most common ones used in HVAC application.

Forced draft cooling tower is a type of mechanical draft tower which has a blower type fan at the air intake. With the fan on the air intake, the fan is more susceptible to complications due to freezing conditions. The benefit of the forced draft design is its ability to work with high static pressure. Such setups can be installed in more-confined spaces and even in some indoor situations. This fan geometry is also known as blow-through. The fan forces air into the tower, creating high entering and low exiting air velocities. The low exiting velocity is much more susceptible to recirculation.
Priyanka G, M. R. Nagraj [1] in their research they carried out with a view to predicting the performance of a shell and finned tube heat exchanger in the light of waste heat recovery application. The performance of the heat exchanger has been evaluated by using the CFD package ANSYS13.0. They made an attempt to predict the performance of the heat exchanger by considering different heat transfer fluid and the result so obtained have been compared. The analysis is carried out and pressure drop and temperature rise along the tube surfaces has been investigated. They found that energy extraction rate is quite significant, that means the effectiveness of exchanger is higher by increasing the contact surface area of hot and cold fluid by using the finned tube heat exchanger.

Mohd Amir, Fithry, Yusoff, MohdZamri [2] in their paper explored the area in the cross-flow cooling tower where the focus on where the porous media or the fill / packing are located and the area in the vicinity for a single phase flow. The behavior of the air intake flow into the cooling tower from the side part through the fill was observed and how it affects the distribution of the air flow inside the fill will be analyzed. The solution of the related governing equation for the basic flow and for flow involving porous media was presented. It was revealed that the porosity introduced a high pressure drop inside the cooling tower. The pressure inside the cooling tower generally is lower that before the porous 
media was introduced. The results also revealed that if the heat transfer inside the porous media is to be improved, higher dynamic pressure inside the cooling tower is required which would result in higher fan power output.

Ramzi R. Ibraheem , Sherzad N. Muhammed [3] in their paper studied the performance of forced draft cooling tower used in central cooling system is studied as experimental work and carried out at residential area in the city of Erbil. Their work includes the estimation of the number of transfer units for the cooling tower of interest and the effect of outside conditions such as air temperature and the inlet water temperature of the cooling tower. The experimental results show the number of transfer unit is increasing by increasing the water to air flow ratio and decreases the approach. The properties of air (temperature, vapor pressure, enthalpy and humidity) are increased by increasing the water to air flow ratio and there was no affect of approach. They estimated that the reduction in the temperature of hot water takes place by $70 \%$ of evaporation and $30 \%$ of heat taken out by the air flowing in counter direction. The effectiveness of water and air is increased by increasing the water to air flow ratio. Increasing the range leads to an increase of many variables and parameters such as number of transfer unit, water and air properties, and heat load through the tower.

Dr. Jalal M. Jalil, Dr.Talib K.Murtadha, Dr. Qasim S. Mehdi [4] conducted numerical and experimental studies for open type forced draft water cooling tower. The numerical part includes a three dimensional computational solution of air and water simultaneous equations which represents the fluid flow, heat transfer and mass transfer. They estimated that high air flow rate gives low approach that leads to increase in effectiveness of cooling tower and also the cold water temperature increases with increment in the air wet bulb temperature. Experimentally, mechanical forced draft counter-flow cooling tower was used to validate the numerical results. The agreement seems acceptable between the numerical and experimental results.

Dr. D. Al. D.H. Alwan Dr. I. W. Maid A. H. Soheel [5] in their article, presents an experimental and numerical investigation of the performance of a forced draft counter flow cooling tower with two kinds of wire mesh packing. The packing used in this study is wire mesh with small square holes (WMSSHSP) and expanded wire mesh with diamond holes (EWMDHSP) configurations. In the numerical investigation, the two dimensional CFD model with finite volume scheme has utilized the standard turbulence model to computes the air properties, while onedimensional model is used to get the water properties. From the results it is concluded that the (EWMDHSP) enhance the performance of the cooling tower. That is due to the pressure drop in the (WMSSHSP) is higher than that for the (EWMDHSP) because air resistance of the former pack is higher than the latter pack. The agreement seems to be acceptable between the numerical and the experimental results.
Nader Pourmahmoud, Amir Hassan Zadeh, Omid Moutaby, And Abdolreza Bramo [6] performed research on the energy separation and flow field behavior of a vortex tube by utilizing both straight and helical nozzles. They mentioned that higher swirl velocity is obtained at $45^{\circ}$ in divergent nozzle and at $30^{\circ}$ in convergent nozzle. Higher swirl velocity due to appropriately nozzle shapes can effectively influence the exit gold gas temperature. Three kinds of nozzles set include of 3 and 6 straight and 3 helical nozzles have been investigated and their principal effects as cold temperature difference was compared by using CFD software.

The refrigeration cycle requires that the heat absorbed from a refrigerated space be rejected and this is done through the condenser where the water from the cooling tower exchanges heat so that it can be discharged by the cooling tower. It is essential that the performance of the cooling tower be improved so the refrigerant cycle can take place at its optimum and hence it increases the effectiveness of the cooling tower. So this project aimed at analyzing whether the change in air inlet parameter enhances the effectiveness or not.

\section{WORKING PRINCIPLE}

All the cooling towers are working on the principle of water evaporation. On evaporation of water, both heat and mass transfer takes place, and water gets cooled. Rate of evaporation is increased by increasing air velocity. In case of cooling tower we call this an air draft. This air draft is created by mechanical system of power driven fan at the bottom of the cooling tower by using a blower. Hot water is sprayed into the tower by using specially designed spray nozzles. Evaporation is a natural phenomenon. Water will evaporate till air in contact with it gets saturated with moisture.

Evaporation cannot be more than the saturation point of air. Thus total evaporation will depend upon the moisture holding capacity of air, which depends on humidity. When hot water is sprayed from top of the cooling tower through our nozzles and air is made to contact from the area surrounding each nozzle. Air and water travel in co current direction down to the basin. During this travel, air cools down the water to desired temperature, and escape through louvers at the top exit.

\section{REFERENCE COOLING TOWER MODEL}

Pioneer cooling towers are a forced draft counter-flow cooling tower with single module capacities from 10 to 100 cooling tons. These towers are a unique design that Delta Cooling Towers [7] has been manufacturing since 1971 and have been very well received in both commercial and industrial applications. 

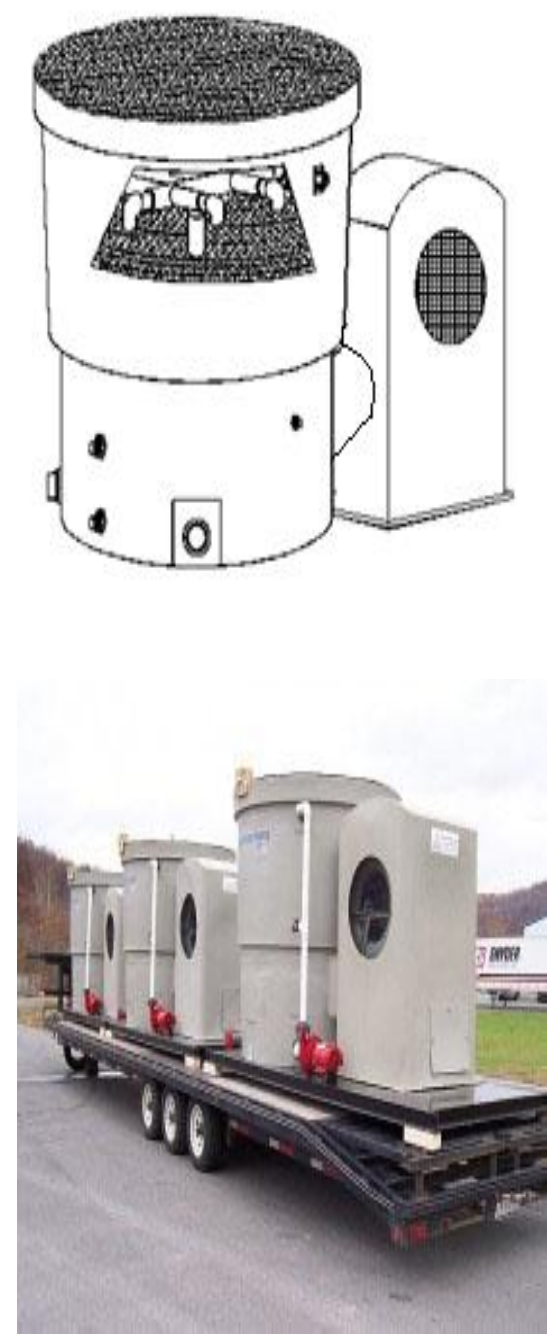

Fig - 1: Reference Model - Pioneer Cooling Tower

The towers are corrosion-proof, which is an important distinction of Delta towers. Cooling towers are outdoor equipment, either on roofs or sides of buildings, and are subjected to weather extremes continuously.

In this project the design considerations are taken for 50 cooling ton capacity.

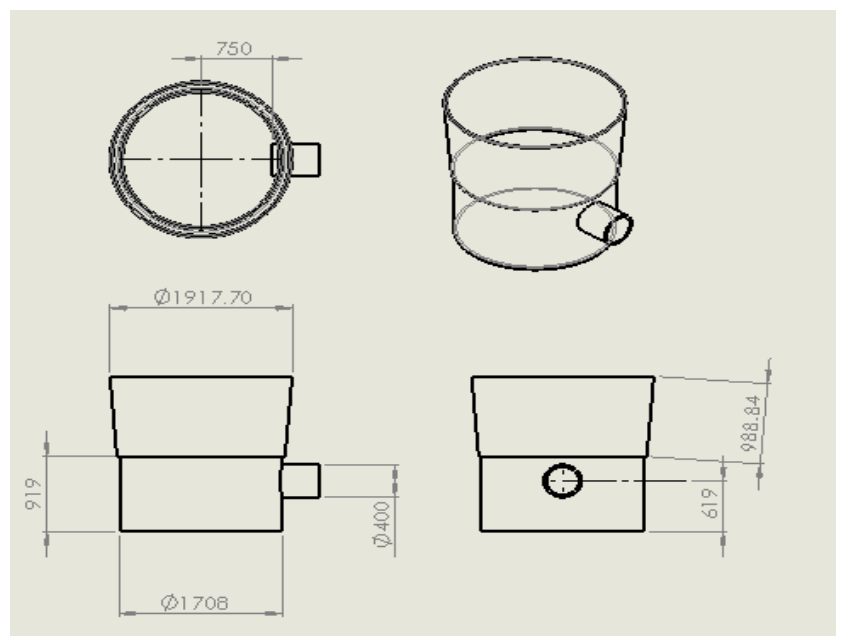

Fig - 2: Cooling Tower Design Specification

\section{MODIFICATIONS IN COOLING TOWER PARAMETERS}

Cooling tower works on the Principle of water evaporation. Based on rate of evaporation, the hot water could be cooled more effectively. The rate of evaporation of hot water by,

$>$ Increasing time of contact of air with hot water.

$>$ Increasing air velocity.

$>$ Increasing area of contact of air and hot water.

Table 1: Modifications in Cooling Tower Parameters

\begin{tabular}{|l|l|}
\hline Objectives & Methodologies \\
\hline $\begin{array}{l}\text { Increasing contact } \\
\text { time of air with hot } \\
\text { water }\end{array}$ & $\begin{array}{l}\text { Changing the air inlet } \\
\text { angle }\end{array}$ \\
\hline $\begin{array}{l}\text { Increasing air } \\
\text { velocity }\end{array}$ & $\begin{array}{l}\text { Implementing } \\
\text { convergent type nozzle }\end{array}$ \\
\hline $\begin{array}{l}\text { Increasing area of } \\
\text { contact of air and } \\
\text { hot water }\end{array}$ & $\begin{array}{l}\text { Nozzle implementation } \\
\text { enhances swirl motion } \\
\text { of air }\end{array}$ \\
\hline
\end{tabular}

\subsection{Air Inlet Pipe Angles}

$>\quad 0^{\circ}$ degree

$>\quad 30^{\circ}$ degree about horizontal axis

$>30^{\circ}$ degree about vertical axis

$>30^{\circ}$ degree about both horizontal and vertical axis

\section{SOLIDWORKS MODELING}

Based on the obtained specification from the reference cooling tower model, the cooling tower has been modeled using Solidworks 2013 Modeling Software.

In this project the performance of this cooling tower has been analyzed by changing the air inlet parameters, by varying air inlet angles as $0^{\circ}, 30^{\circ}$ horizontally, $30^{\circ}$ vertically, $30^{\circ}$ both horizontally and vertically. These varied air inlet angle models have been designed without changing any other parameters of reference model. Then these 4 models have been again modeled by assembling convergent nozzle at the air inlet. Totally 8 cooling tower models have been modeled and analyzed.

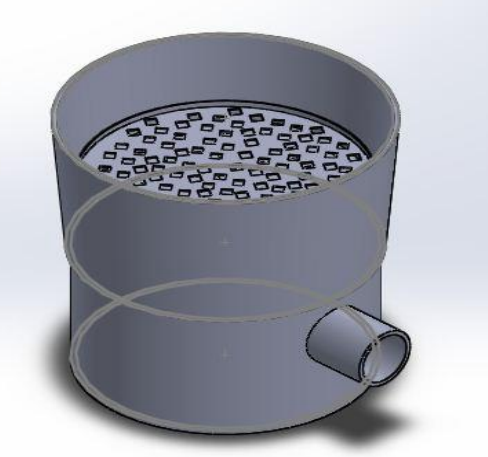

Fig - 3: Isometric View of Cooling Tower Model 


\subsection{Varied Air Inlet Angles without Nozzle}

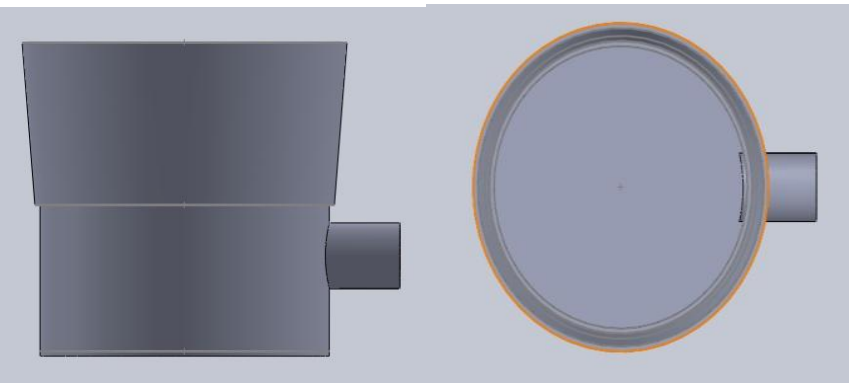

Fig - 4: Air Inlet Pipe at $0^{\circ}$ Cooling Tower Model

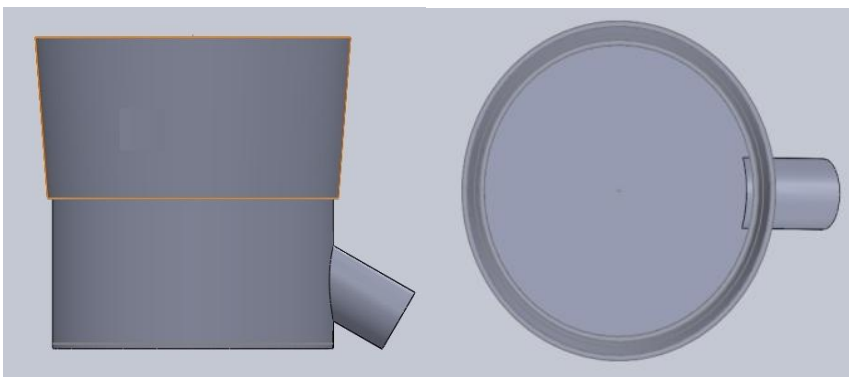

Fig - 5: Air Inlet Pipe at $30^{\circ}$ Inclined Horizontally-Cooling Tower Model

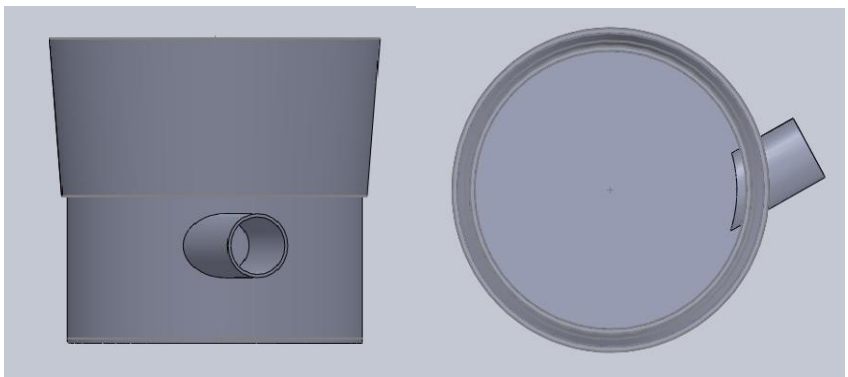

Fig - 6: Air Inlet Pipe at $30^{\circ}$ Inclined Vertically-Cooling Tower Model

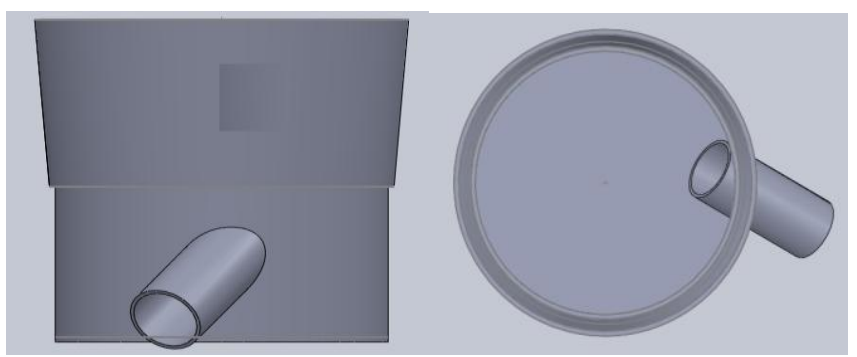

Fig - 7: Air Inlet Pipe at $30^{\circ}$ Inclined Horizontally and Vertically-Cooling Tower Model

\subsection{Convergent Nozzle Modeling}

The convergent type nozzle has been designed and implemented at the air inlet pipe inside the cooling tower shell in order to increase the air velocity and enhancing swirl motion of air inside the shell, so that the air and water contact will be comparatively increased that enhance the rate of evaporation of hot water. For convergent nozzle, the swirl motion is high at $30^{\circ}$ convergence angle. Based on this specification the nozzle is designed and modeled.
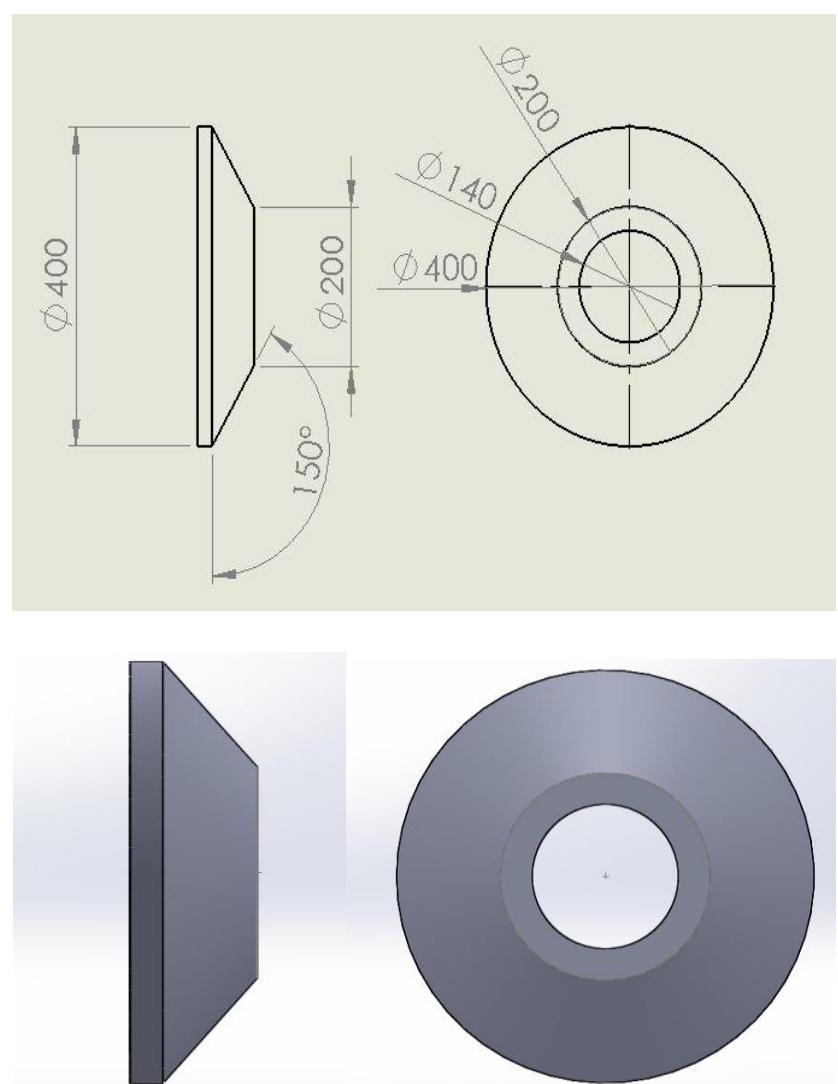

Fig - 8: Convergent Nozzle Model

\subsection{Nozzle Assembled Cooling Tower Models}

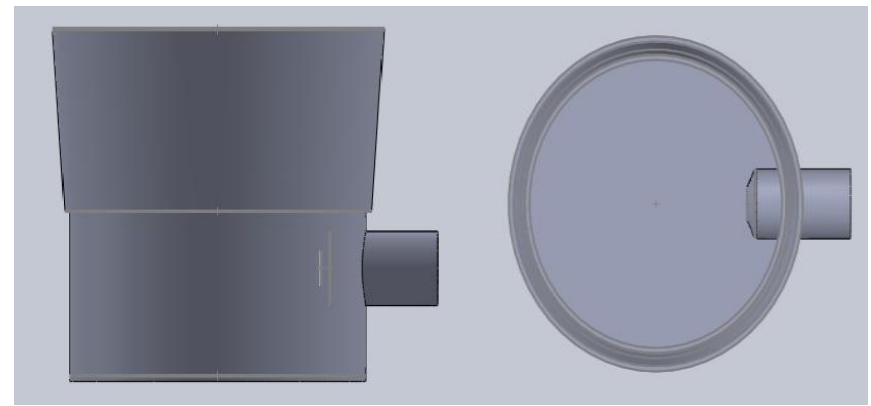

Fig - 9: Air Inlet Pipe at $0^{\circ}$ with Nozzle-Cooling Tower Model

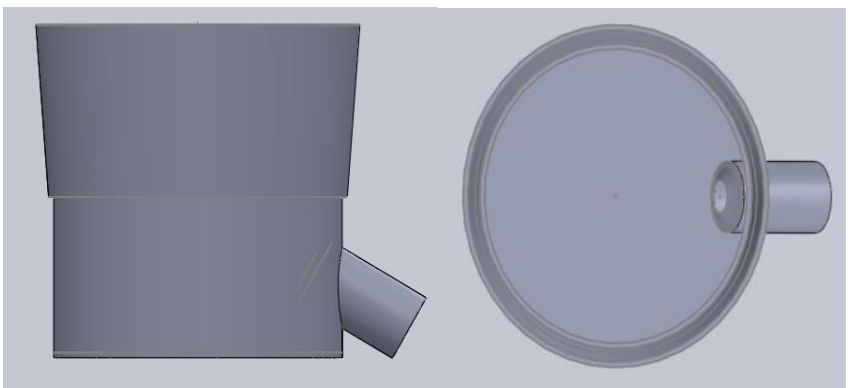

Fig - 10: Air Inlet Pipe $30^{\circ}$ Inclined Horizontally With Nozzle-Cooling Tower Model 


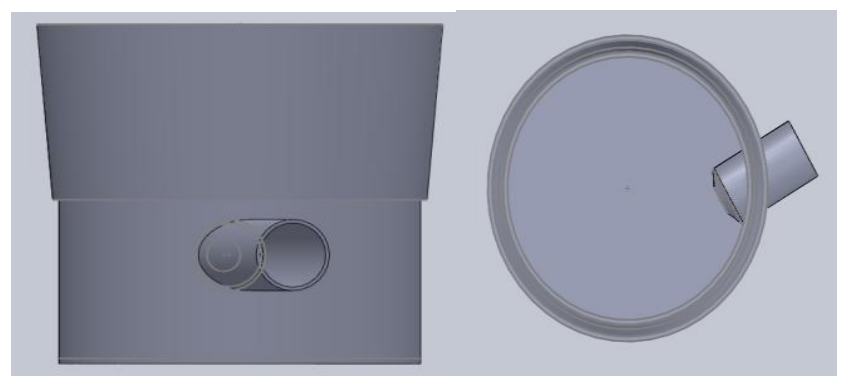

Fig - 11: Air Inlet Pipe $30^{\circ}$ Inclined Vertically with NozzleCooling Tower Model

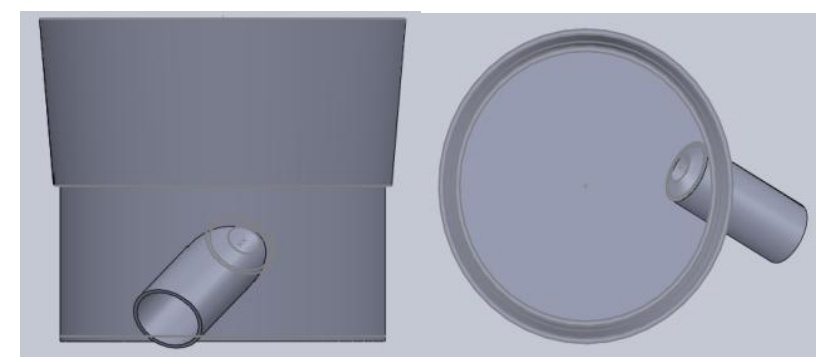

Fig - 12: Air Inlet Pipe $30^{\circ}$ Inclined Vertically and Horizontally With Nozzle-Cooling Tower Model

\section{CFD PREPROCESSING}

The cooling tower models have been imported as the geometries into IGES (Initial Graphics Exchange Specification) format. Then the models have been meshed using ICEM CFD software.

For improved element quality, the Tetra mesher incorporates a powerful smoothing algorithm, as well as tools for local adaptive mesh refinement and coarsening.

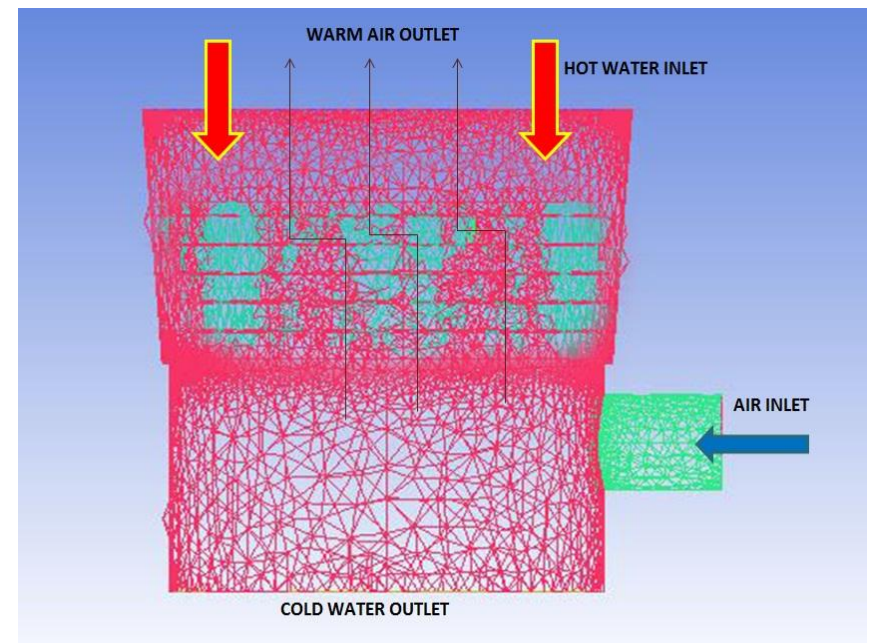

Fig - 13: Meshed Model of Cooling Tower with $0^{0}$ Air Inlet Pipe

All the 8 cooling tower models are meshed and its geometrics are repaired and then imported to FLUENT software and boundary conditions are applied and the solution has been initialized. Figure 13 shows the meshed model of cooling tower with $0^{\circ}$ air inlet pipe.

\subsection{Mesh Details}

Total no of elements $=188943$

Total no of nodes $\quad=\quad 31060$

\section{Surface Mesh}

No of shells $\quad=9100$

Volume Mesh

No of cells $\quad=171887$

\subsection{Boundary Conditions Applied}

$>$ Air inlet diameter, $\mathrm{D}_{\mathrm{A}} \quad=0.18 \mathrm{~m}$

$>$ Water inlet diameter, $\mathrm{D}_{\mathrm{W}} \quad=1.66 \mathrm{~m}$

$>$ Mass flow rate of water, $\mathrm{m}_{\mathrm{W}}=0.055 \mathrm{~kg} / \mathrm{s}$

$>$ Mass flow rate of air, $\mathrm{m}_{\mathrm{A}} \quad=0.0404 \mathrm{~kg} / \mathrm{s}$

$>$ Water inlet temperature, $\mathrm{T}_{1}=329 \mathrm{~K}$

$>$ Air inlet WB temperature, $\mathrm{T}_{\mathrm{WB}}=300 \mathrm{~K}$

\section{ANALYZED COOLING TOWER MODELS}

The imported models are solved by applying boundary conditions, the solution is initialized and the temperature contours have been obtained after the solution convergence criteria get reached up to its minimum value. The analyzed cooling tower models are displayed below, 


\subsection{Air Inlet Pipe at $0^{\circ}$ without Nozzle}
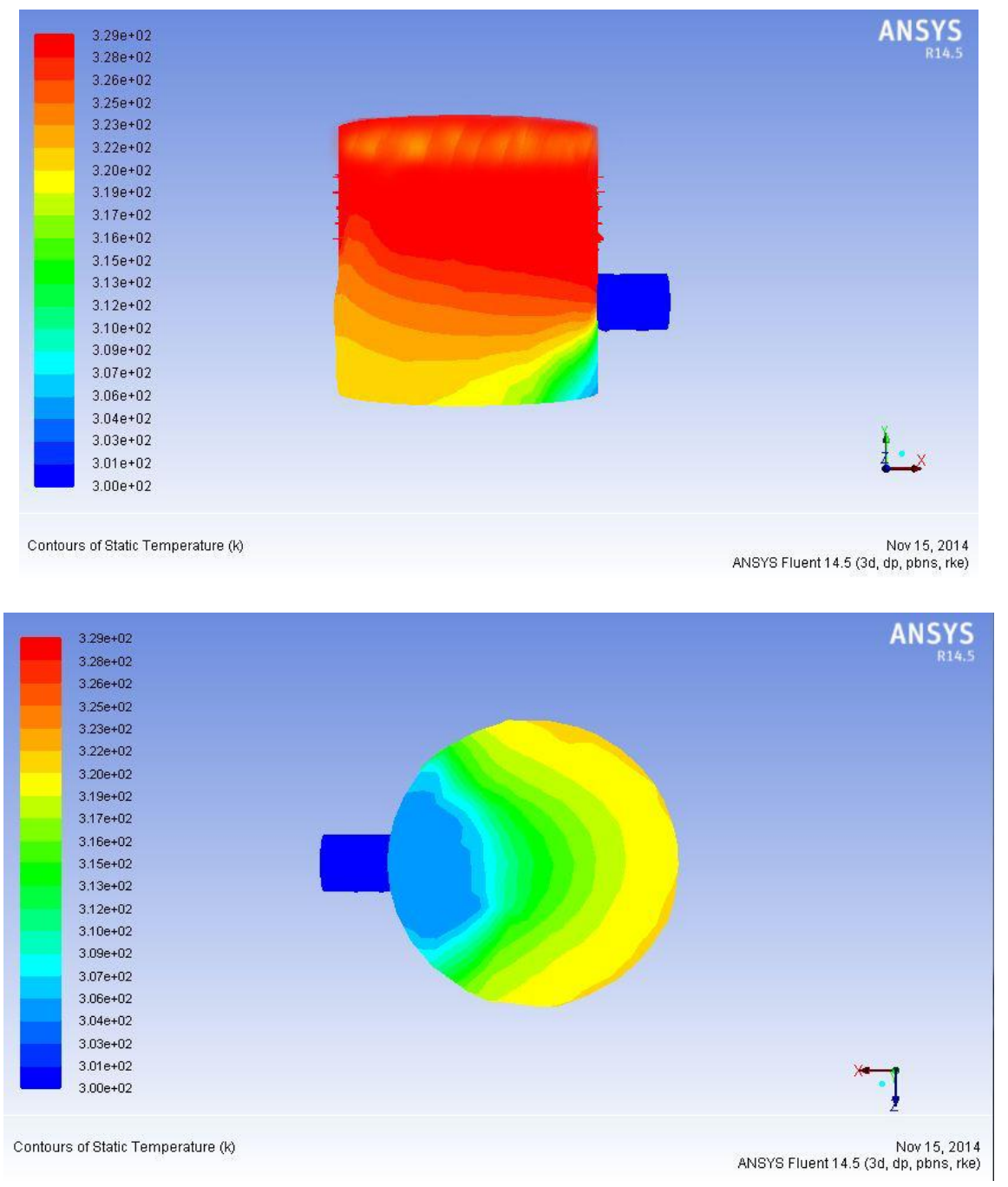

Fig - 14: Temperature Contours for Cooling Tower - Air Inlet Pipe at $0^{\circ}$

\begin{tabular}{|c|c|}
\hline Air Inlet Temperature & $300 \mathrm{~K}$ \\
\hline Water Inlet Temperature & $329 \mathrm{~K}$ \\
\hline Water Outlet Temperature & $\mathbf{3 0 4} \mathbf{~ K}$ \\
\hline
\end{tabular}

\subsection{Air Inlet Pipe at $30^{\circ}$ Inclined Horizontally without Nozzle}




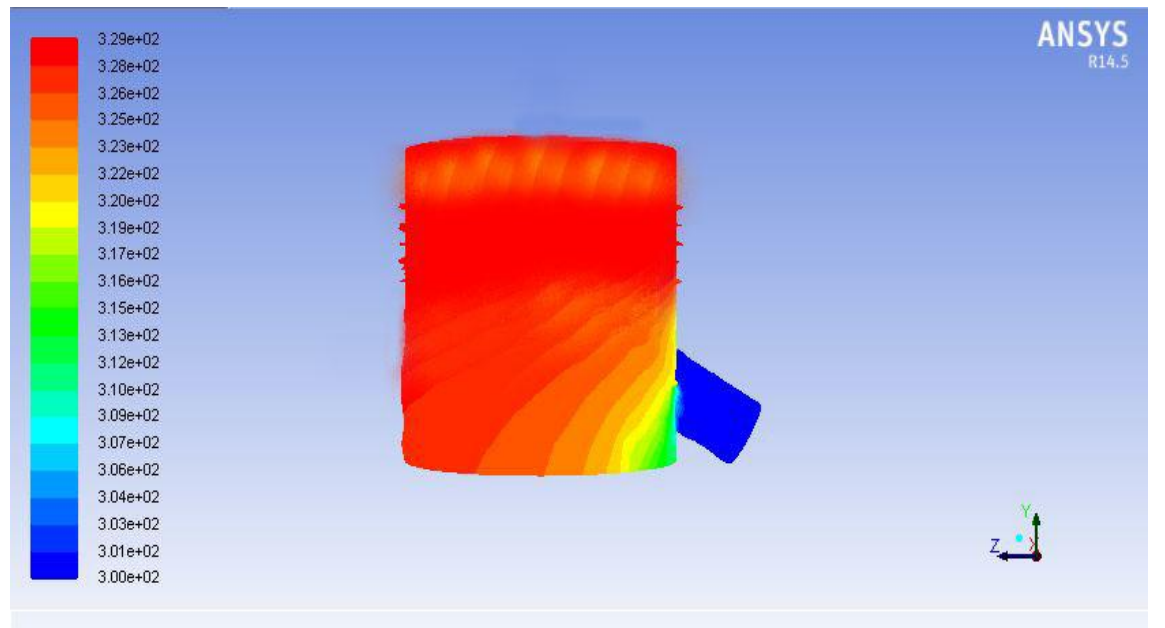

Contours of Static Temperature $(k)$

Nov 25, 2014

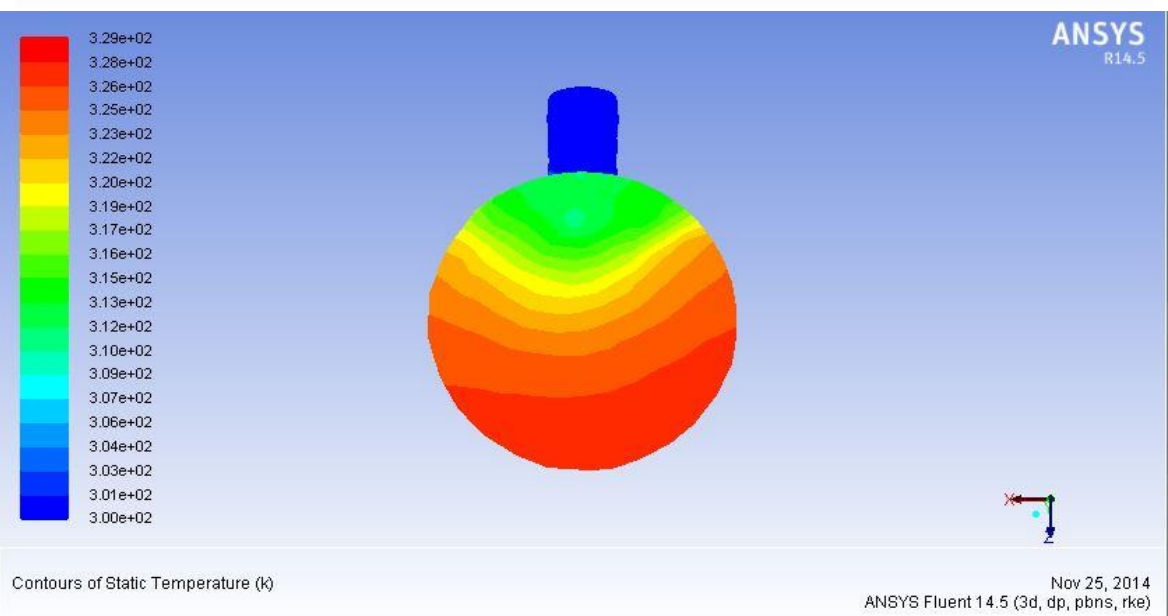

Fig - 15: Temperature Contours for Cooling Tower - Air Inlet Pipe at $30^{\circ}$ Inclined Horizontally

\begin{tabular}{|c|c|}
\hline Air inlet temperature & $300 \mathrm{k}$ \\
\hline Water inlet temperature & $329 \mathrm{k}$ \\
\hline Water outlet temperature & $\mathbf{3 1 2} \mathbf{~ k}$ \\
\hline
\end{tabular}

\subsection{Air Inlet Pipe $30^{\circ}$ Inclined Vertically without Nozzle}

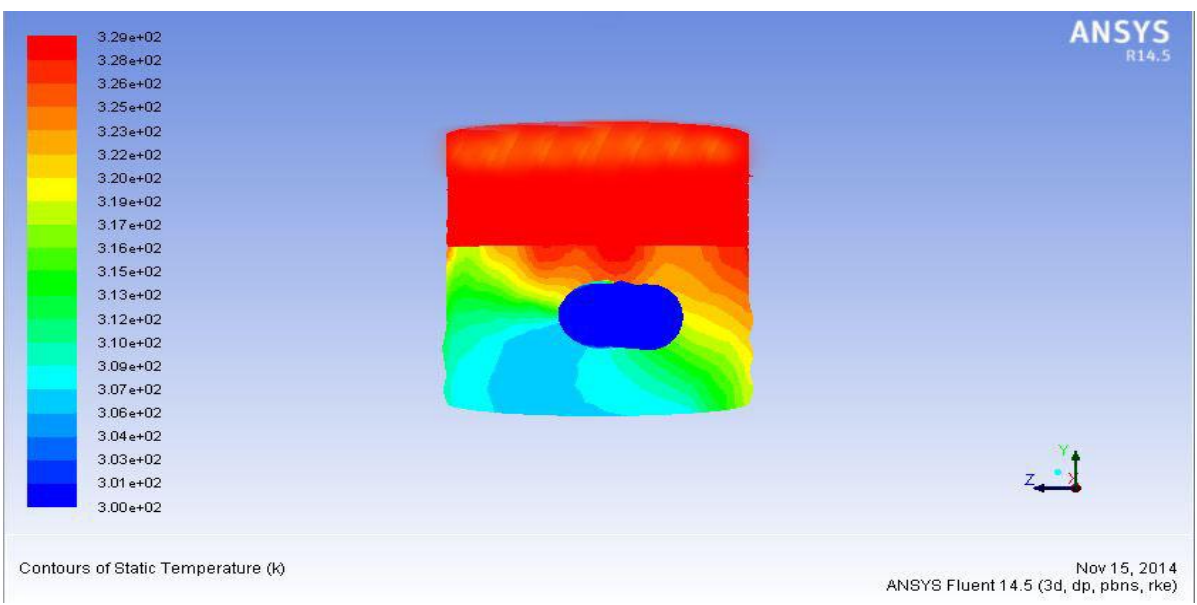




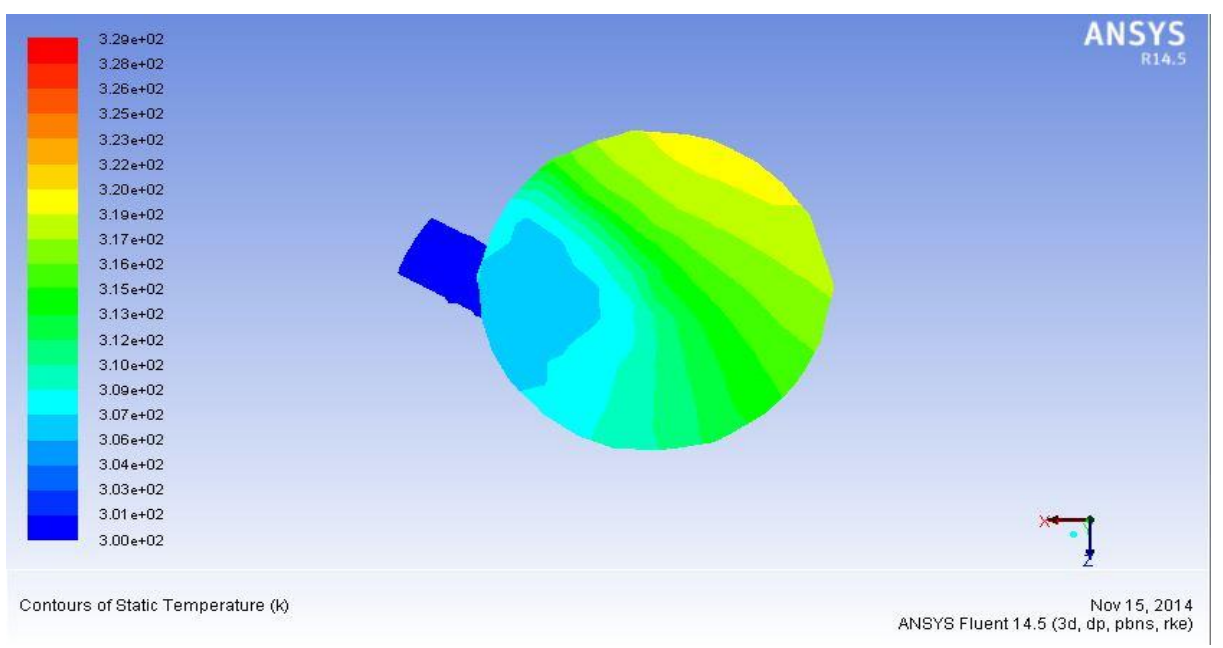

Fig - 16: Temperature Contours for Cooling Tower - Air Inlet Pipe at $30^{\circ}$ Inclined Horizontally

\begin{tabular}{|c|c|}
\hline Air Inlet Temperature & $300 \mathrm{~K}$ \\
\hline Water Inlet Temperature & $329 \mathrm{~K}$ \\
\hline Water Outlet Temperature & $\mathbf{3 0 7} \mathbf{~ K}$ \\
\hline
\end{tabular}

\subsection{Air Inlet Pipe $30^{\circ}$ Inclined about Vertically \& Horizontally without Nozzle}
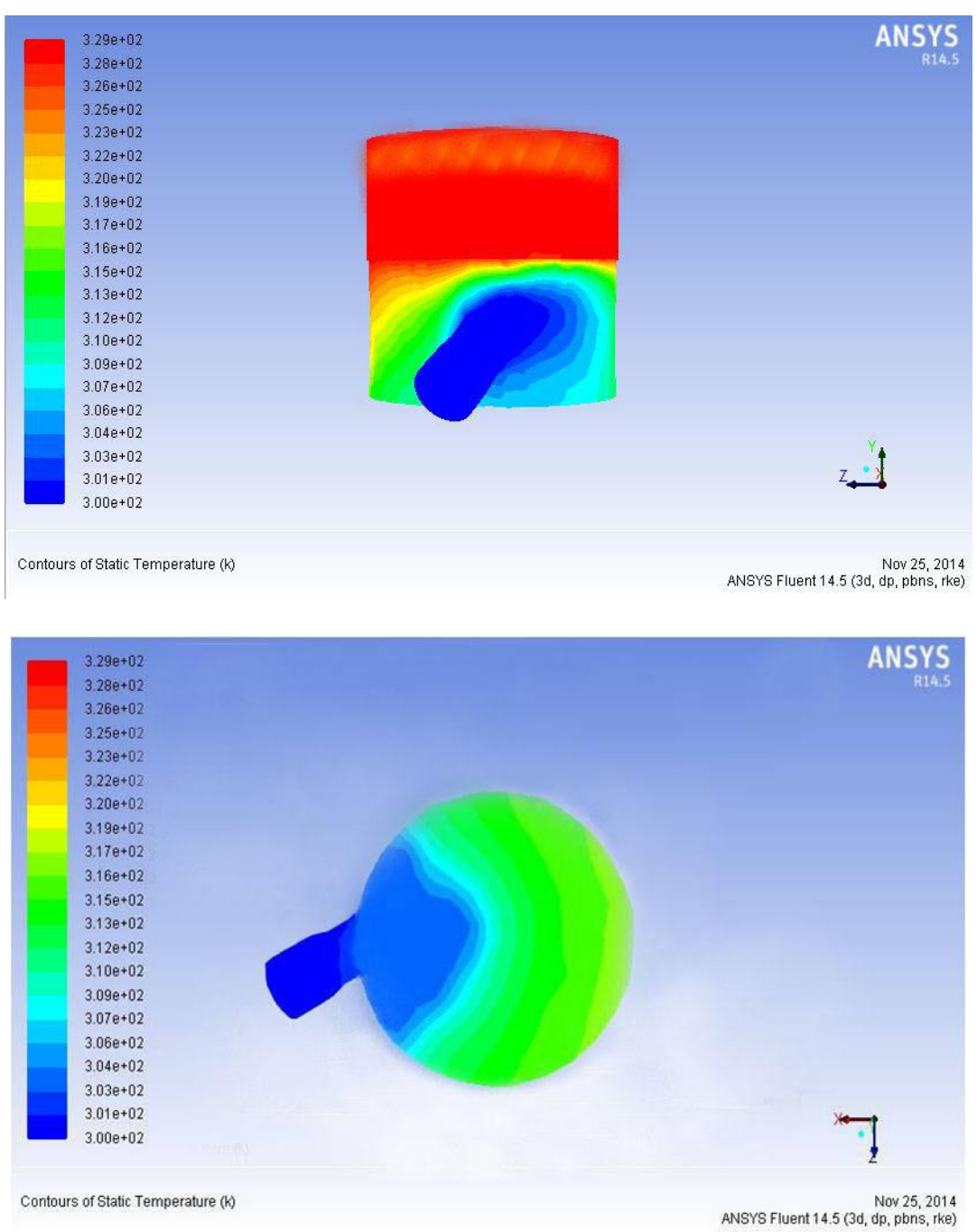

Fig - 17: Temperature Contours for Cooling Tower - Air Inlet Pipe at $30^{\circ}$ Inclined Vertically and Horizontally

\begin{tabular}{|c|c|}
\hline Air Inlet Temperature & $300 \mathrm{~K}$ \\
\hline
\end{tabular}




\begin{tabular}{|c|c|}
\hline Water Inlet Temperature & $329 \mathrm{~K}$ \\
\hline Water Outlet Temperature & $\mathbf{3 0 3} \mathbf{~ K}$ \\
\hline
\end{tabular}

\subsection{Air Inlet Pipe at $0^{\circ}$ with Nozzle}

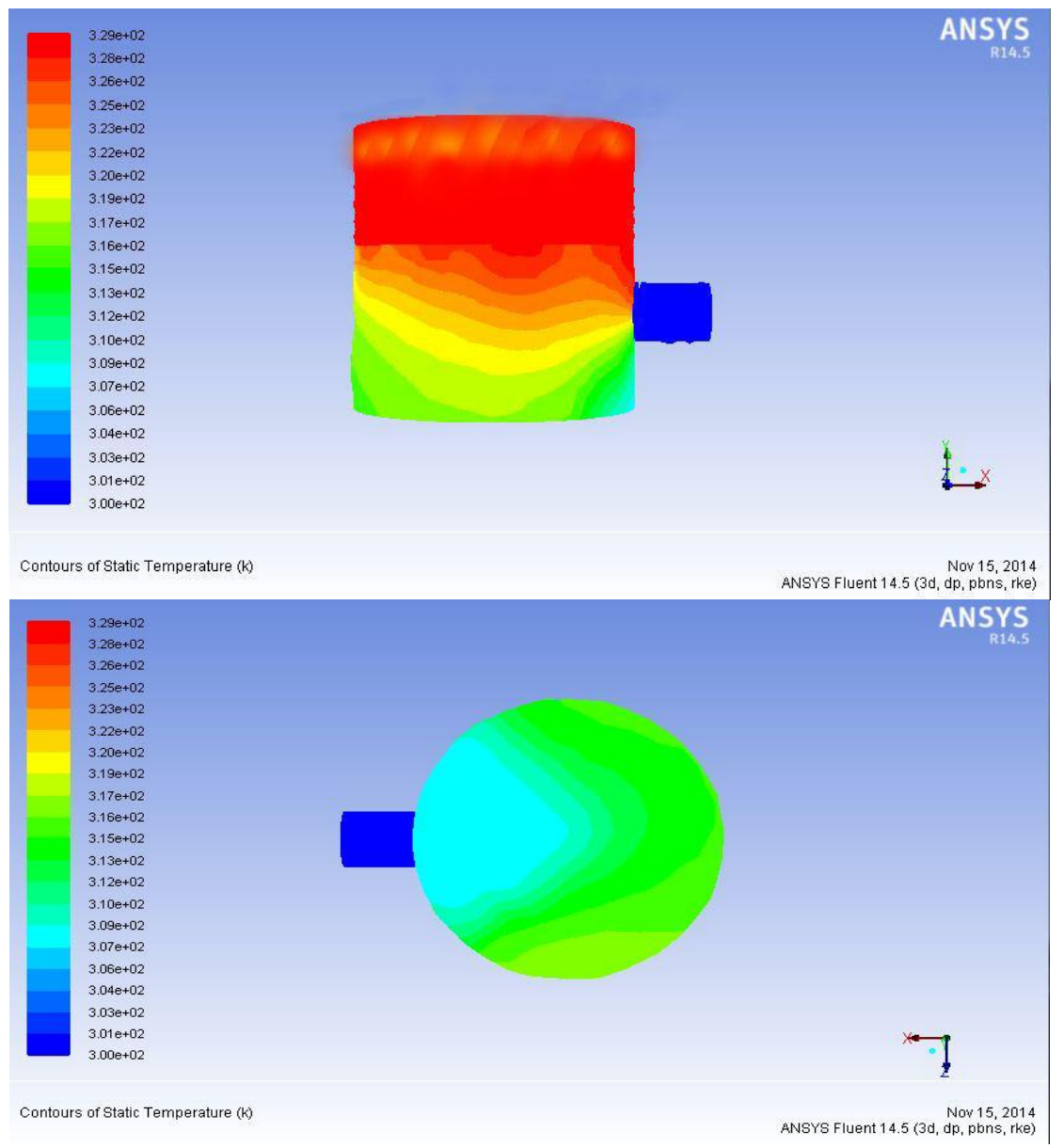

Fig - 18: Temperature Contours for Cooling Tower - Air Inlet Pipe at $0^{\circ}$ with Nozzle

\begin{tabular}{|l|l|}
\hline Air Inlet temperature & $300 \mathrm{~K}$ \\
\hline Water Inlet Temperature & $329 \mathrm{~K}$ \\
\hline Water Outlet Temperature & $\mathbf{3 0 9} \mathbf{~ K}$ \\
\hline
\end{tabular}

\subsection{Air Inlet Pipe at $30^{\circ}$ Inclined Horizontally with Nozzle}

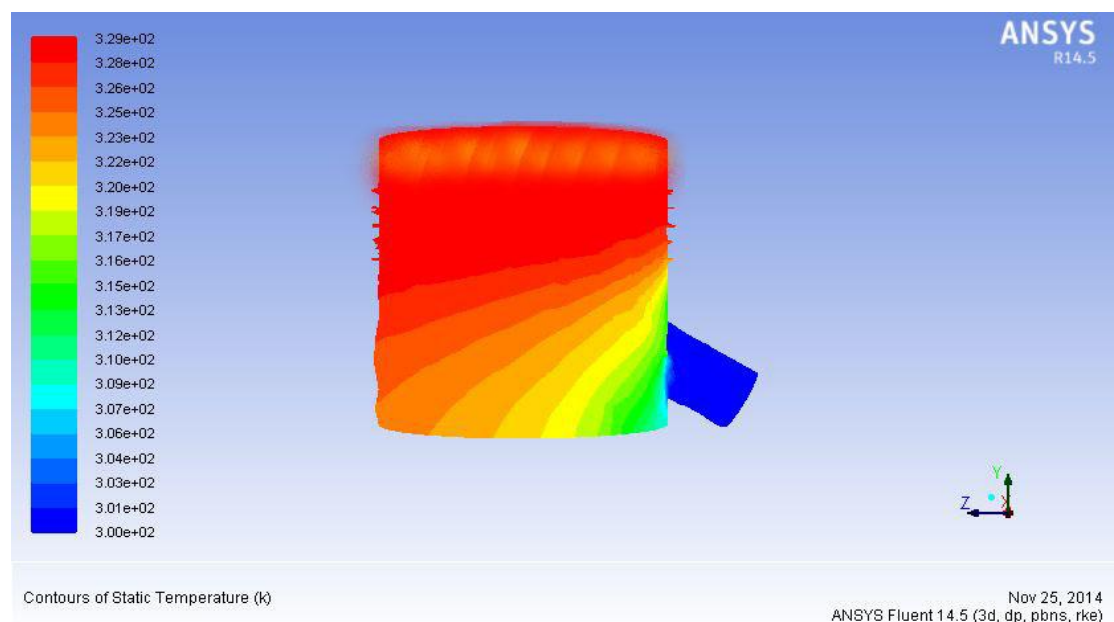




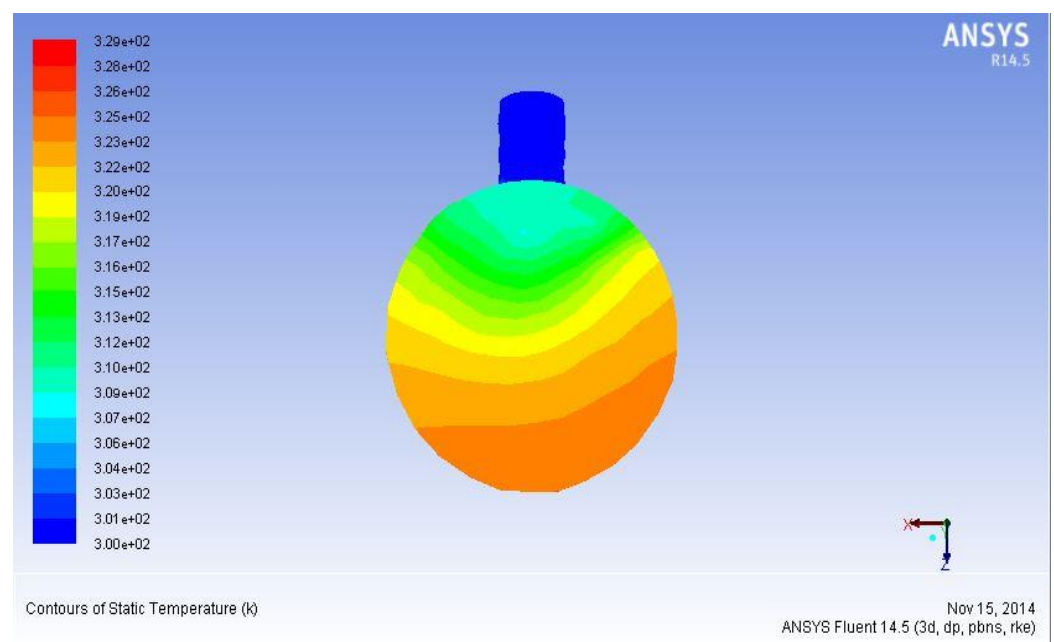

Fig - 19: Temperature Contours for Cooling Tower - Air Inlet Pipe at $30^{\circ}$ Inclined Horizontally with Nozzle

\begin{tabular}{|l|l|}
\hline Air Inlet temperature & $300 \mathrm{~K}$ \\
\hline Water Inlet Temperature & $329 \mathrm{~K}$ \\
\hline Water Outlet Temperature & $\mathbf{3 1 0} \mathbf{~ K}$ \\
\hline
\end{tabular}

\subsection{Air Inlet Pipe at $30^{\circ}$ Inclined Vertically with Nozzle}
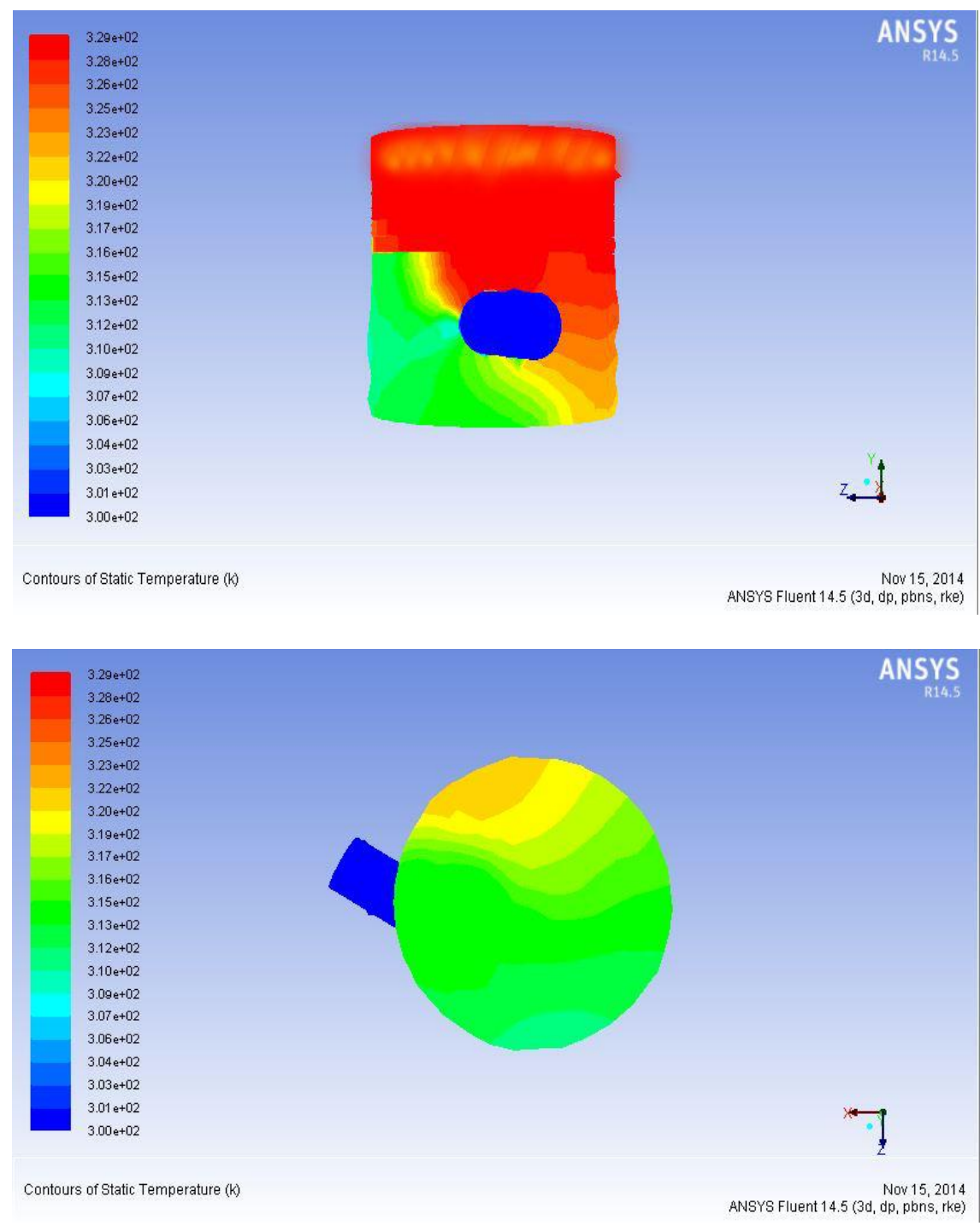

Fig - 20: Temperature Contours for Cooling Tower - Air Inlet Pipe at $30^{\circ}$ Inclined Vertically with Nozzle 


\begin{tabular}{|l|l|}
\hline Air Inlet temperature & $300 \mathrm{~K}$ \\
\hline Water Inlet Temperature & $329 \mathrm{~K}$ \\
\hline Water Outlet Temperature & $\mathbf{3 1 3 ~ K}$ \\
\hline
\end{tabular}

\subsection{Air Inlet Pipe $30^{\circ}$ Inclined about Vertically \& Horizontally with Nozzle}

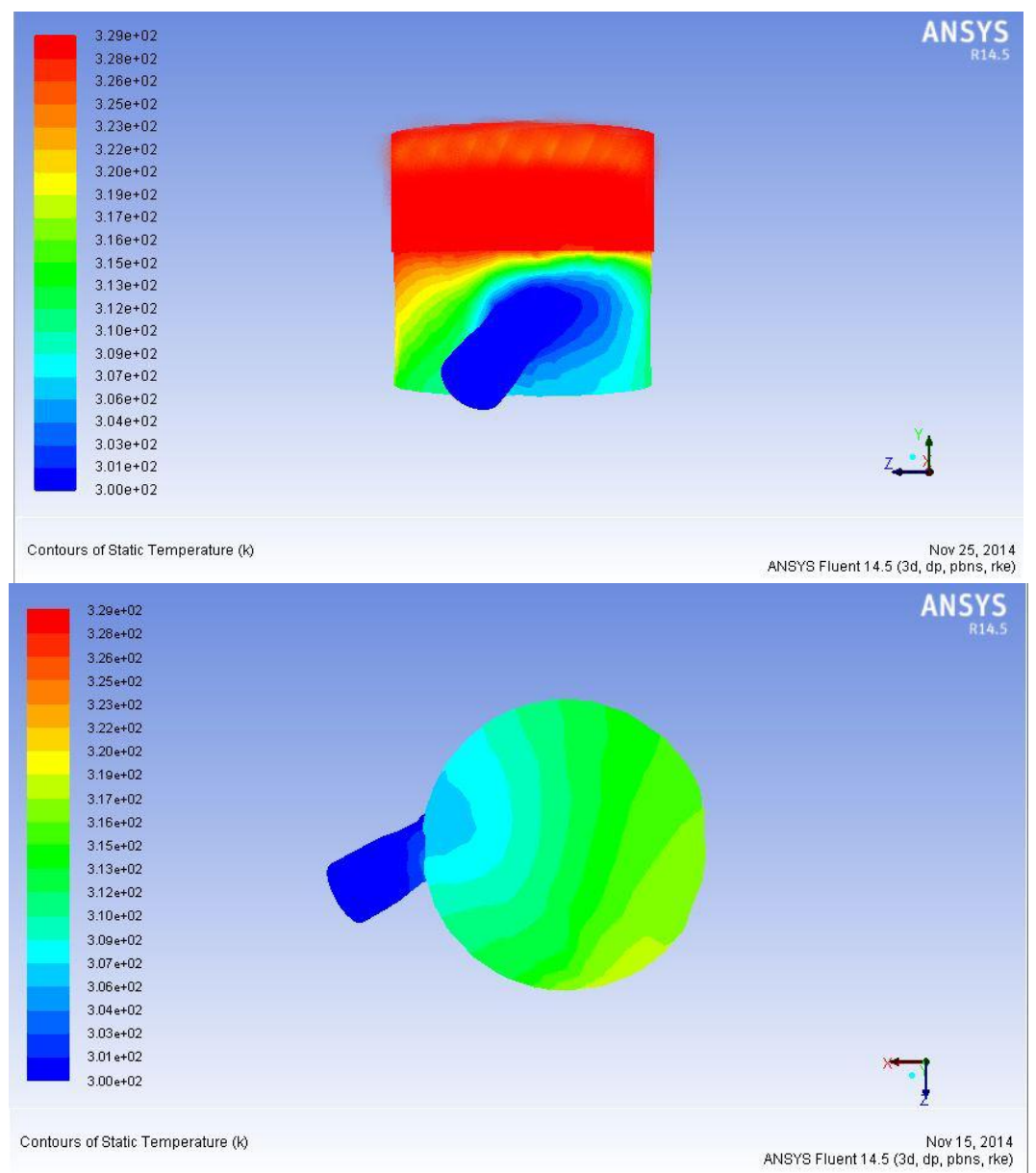

Fig - 21: Temperature Contours for Cooling Tower - Air Inlet Pipe at $30^{\circ}$ Inclined Vertically and Horizontally with Nozzle

\begin{tabular}{|l|l|}
\hline Air Inlet temperature & $300 \mathrm{~K}$ \\
\hline Water Inlet Temperature & $329 \mathrm{~K}$ \\
\hline Water Outlet Temperature & $\mathbf{3 0 6} \mathbf{~ K}$ \\
\hline
\end{tabular}

8. COOLING TOWER PERFORMANCE CT Effectiveness $(\%)=[$ Range $/($ Range + Approach $)] \times 100$

\section{ANALYSIS CALCULATION}

Formulae:

I. Range

$$
\text { CT Range }(\mathrm{K})=\mathrm{T}_{1}-\mathrm{T}_{2}
$$

\section{Approach}

$$
\text { CT Approach }(\mathrm{K})=\mathrm{T}_{2}-\mathrm{T}_{\mathrm{WB}}
$$

\section{Effectiveness}

\section{Evaporation loss}

Evaporation loss $\left(\right.$ E.L) $\left(\mathrm{m}^{3} / \mathrm{hr}\right)=0.00085 \times 1.8 \times \mathrm{Q}_{\mathrm{W}} \times\left(\mathrm{T}_{1}-\right.$ $\mathrm{T}_{2}$ )

\section{Percentage evaporation loss}

Percentage evaporation loss $(\%)=\left(\right.$ E.L / Q $\left.\mathrm{W}_{\mathrm{W}}\right) \times 100$

Where,

$\mathrm{T}_{1} \quad$ - Hot water inlet temp (K)

$\mathrm{T}_{2} \quad$ - Cold water outlet temp $(\mathrm{K})$

$\mathrm{T}_{\mathrm{WB}} \quad$ - Air Wet bulb temp (K)

$\mathrm{Q}_{\mathrm{W}} \quad$ - Water Circulation rate $\left(\mathrm{m}^{3} / \mathrm{hr}\right)$ 


\section{Case 1: Air inlet pipe at $0^{\circ}$}

$\mathrm{T}_{1}=329 \mathrm{~K}, \mathrm{~T}_{2}=304 \mathrm{~K}, \mathrm{~T}_{\mathrm{WB}}=300 \mathrm{~K}, \mathrm{Q}_{\mathrm{W}}=0.198 \mathrm{~m}^{3} / \mathrm{hr}$

i. CT Range $\left({ }^{\circ} \mathrm{C}\right)=\mathrm{T}_{1}-\mathrm{T}_{2}=329-304=25 \mathrm{~K}$

ii. CT Approach $\left({ }^{\circ} \mathrm{C}\right)=\mathrm{T}_{2}-\mathrm{T}_{\mathrm{WB}}=304-300=\mathbf{4} \mathbf{K}$

iii. CT Effectiveness $(\%)=\quad[$ Range / $($ Range + Approach)] x 100

$=[25 /(25+4)] \times 100=\mathbf{8 6 . 2 1 \%}$

iv. Evaporation loss $($ E.L $)=0.00085 \times 1.8 \times \mathrm{Q}_{\mathrm{W}} \times\left(\mathrm{T}_{1}-\mathrm{T}_{2}\right)$ $=0.00085 \times 1.8 \times 0.198 \times(329-304)=\mathbf{7 . 5 7 3 5} \times 10^{-3} \mathbf{m}^{3} / \mathbf{h r}$

v. Percentage evaporation loss $(\%)=($ E.L / Q $\mathrm{W}) \times 100$

$=\left(7.5735 \times 10^{-3} / 0.198\right) \times 100=\mathbf{3 . 8 2 5} \%$

\section{RESULTS AND DISCUSSION}

By using above formulae, the performance parameters of all 8 cooling tower models have been found out and tabulated and graphed as follows,

\subsection{Calculation Tabulation}

Table 2: Calculated Performance Parameters for all 8 Cooling Tower Models

\begin{tabular}{|l|l|l|l|}
\hline Models & Effectiveness & $\begin{array}{l}\text { Evaporation } \\
\text { loss }\end{array}$ & $\begin{array}{l}\text { Percentage } \\
\text { evaporatio } \\
\text { n loss }\end{array}$ \\
\hline Units & $\%$ & $\mathrm{~m}^{3} / \mathrm{hr}$ & $\%$ \\
\hline I & 86.21 & $7.5735 \times 10^{-3}$ & 3.825 \\
\hline II & 58.62 & $5.149 \times 10^{-3}$ & 2.601 \\
\hline III & 75.86 & $6.666 \times 10^{-3}$ & 3.366 \\
\hline IV & 87.66 & $7.876 \times 10^{-3}$ & 3.978 \\
\hline V & 68.97 & $6.058 \times 10^{-3}$ & 3.062 \\
\hline VI & 65.52 & $5.756 \times 10^{-3}$ & 2.907 \\
\hline VII & 55.17 & $4.847 \times 10^{-3}$ & 2.448 \\
\hline VIII & 79.31 & $6.968 \times 10^{-3}$ & 3.519 \\
\hline
\end{tabular}

\subsection{Performance Graph}

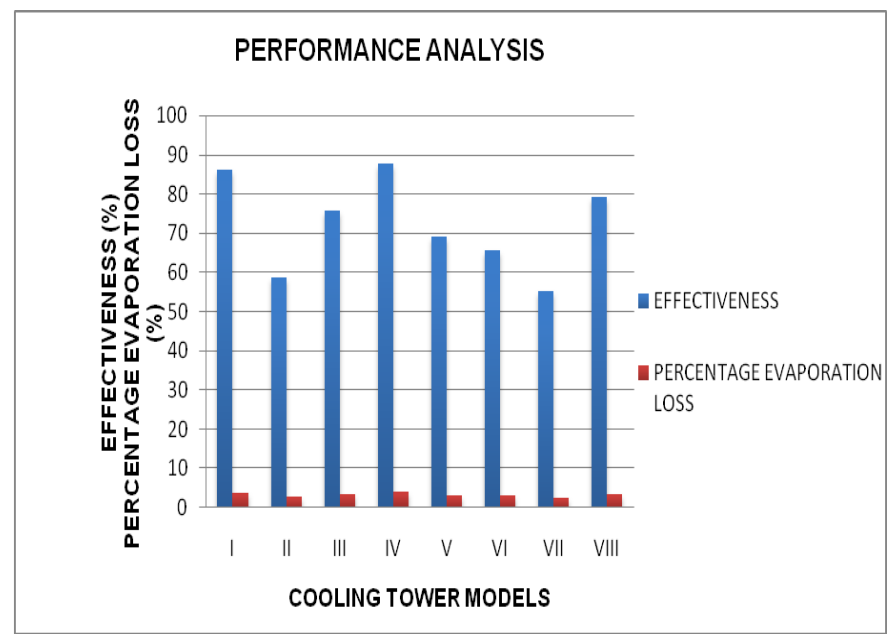

Fig - 22: Performance Graph comparing all 8 Cooling Tower Models

I - Air Inlet Pipe at $0^{\circ}$ without Nozzle

II - Air Inlet Pipe at $30^{\circ}$ Inclined Horizontally without Nozzle

III - Air Inlet Pipe at $30^{\circ}$ Inclined Vertically without Nozzle

IV - Air Inlet Pipe at $30^{\circ}$ Inclined Vertically \& Horizontally without Nozzle

$\mathrm{V}$ - Air Inlet Pipe at $0^{\circ}$ with Nozzle

VI - Air Inlet Pipe at $30^{\circ}$ Inclined Horizontally with Nozzle

\begin{tabular}{|l|l|l|l|l|l|}
\hline $\begin{array}{l}\text { Model } \\
\text { s }\end{array}$ & $\begin{array}{l}\text { Water } \\
\text { inlet } \\
\text { temp }\end{array}$ & $\begin{array}{l}\text { Air } \\
\text { inlet } \\
\text { temp }\end{array}$ & $\begin{array}{l}\text { Water } \\
\text { outlet } \\
\text { temp }\end{array}$ & $\begin{array}{l}\text { Rang } \\
\text { e }\end{array}$ & Approach \\
\hline Units & K & K & K & K & K \\
\hline I & 329 & 300 & 304 & 25 & 4 \\
\hline II & 329 & 300 & 312 & 17 & 12 \\
\hline III & 329 & 300 & 307 & 22 & 7 \\
\hline IV & 329 & 300 & 303 & 26 & 3 \\
\hline V & 329 & 300 & 309 & 20 & 9 \\
\hline VI & 329 & 300 & 310 & 19 & 10 \\
\hline VII & 329 & 300 & 313 & 16 & 13 \\
\hline VIII & 329 & 300 & 306 & 23 & 6 \\
\hline
\end{tabular}

VII - Air Inlet Pipe at $30^{\circ}$ Inclined Vertically with Nozzle VIII - Air Inlet Pipe at $30^{\circ}$ Inclined Vertically \& Horizontally with Nozzle

\subsection{Discussion}

From the results of analyzed 8 models of cooling tower, the reference cooling tower model has effectiveness of about $\mathbf{8 6 . 2 1 \%}$, meanwhile the modified cooling tower model with air inlet pipe inclined at $30^{\circ}$ about both horizontal and vertical axis have derived an improved effectiveness of about $87.66 \%$.

Hence the evaporation rate characteristic between air and water have been varied for cooling tower models due to the change in contact surface of air and water which have been caused by varying air inlet angles. 
As the rate of evaporation has been changing, the amount of cold water exiting at the outlet varied due to the evaporation of water. If the rate of evaporation increases then the effectiveness increases that leads to loss of some amount of cold water at the outlet which is considered as the evaporation loss. As the improved effectiveness model has increased rate of evaporation, the evaporation loss has also been increased, that leads to loss of some amount of water. This lost water quantity has to be compensated by make-up water supply.

Nozzle assembled cooling tower models also show variations in the outlet water temperature, but improvement in effectiveness has not been obtained, hence this modification of air inlet pipe - nozzle assemblage has not reach the expected objective of effectiveness enhancement.

\section{CONCLUSION}

On comparing the effectiveness values of 8 cooling tower models, the cooling tower with air inlet pipe at $0^{\circ}$ and the cooling tower with air inlet pipe inclined at $30^{\circ}$ about both horizontal and vertical axis have nearly same effectiveness. Hence both models could be validated experimentally and implemented for forced draft cooling towers specifically for small scale industries. Nozzle assembled air inlet pipe cooling tower models have not obtained any performance enhancement.

\section{REFERENCES}

[1] Priyanka G, M. R. Nagraj, "CFD Analysis of Shell and Tube Heat Exchanger With and Without Fins for Waste Heat Recovery Applications", International Journal of Science and Research (IJSR) ISSN: 23197064 (Online).

[2] Mohd Amir, Fithry, Yusoff, MohdZamri, "Numerical Investigation of a Single Phase Air Flow inside Porous Media of a Cross Flow Cooling Tower", International Journal of Science and Research (IJSR), ISSN: 2319-7064 (Online).

[3] Ramzi R. Ibraheem, Sherzad N. Muhammed, "Study Performance of Forced Draft Counter Flow Cooling Tower", International Journal of Advances in Engineering Science and Technology ISSN: 23191120 (Journal).

[4] Dr. Jalal M. Jalil, Dr.Talib K.Murtadha, Dr. Qasim S. Mehdi, "CFD Prediction of Forced Draft CounterFlow Cooling Tower Performance", Eng. \&Tech. Journal, Vol.28, No.11, 2010. (Journal)

[5] Dr. D. Al. D.H. Alwan Dr. I. W. Maid A. H. Soheel, "Numerical and Experimental Study of Counter Flow Cooling Tower Performance with Difference Packs Porosity and Configuration", Alwan Technical Report at Baghdad. (Technical Report)

[6] Nader Pourmahmoud, Amir Hassan Zadeh, Omid Moutaby, And Abdolreza Bramo, "Computational Fluid Dynamics Analysis of Helical Nozzles Effects on the Energy Separation in a Vortex Tube", Thermal
Science, Year 2012, Vol. 16, No. 1, Pg. 151-166. (Journal)

[7] "General Design Brochure", DELTA Cooling Towers, Inc., PIONEER®, Forced Draft, Counter Flow Design, 10 - 100 Ton Single Modules. (Design Brochure)

[8] "ASHRAE Systems and Equipment Hand Book" (2000), Cooling Towers, Chapter 39. (Hand Book)

[9] “An Introduction to Computational Fluid Dynamics", Chapter 20 in Fluid Flow Handbook by Nasser Ashgriz \& Javad Mostaghimi, Department of Mechanical \& Industrial Eng., University of Toronto Toronto, Ontario.(Handbook)

\section{BIOGRAPHIES}

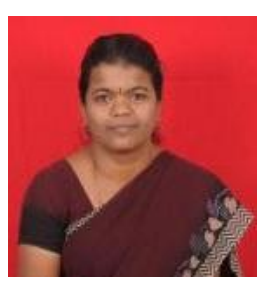

S. Parimala Murugaveni received B.E Mechanical Engineering in Sri Ramakrishna Engineering College, Coimbatore, Tamil Nadu, India and received M.E Engineering Design in Government College of Technology, Coimbatore, Tamil Nadu, India and now she is working as Assistant Professor (Senior Grade) of Mechanical Engineering Department in Government College of Technology, Coimbatore, Tamil Nadu, India.

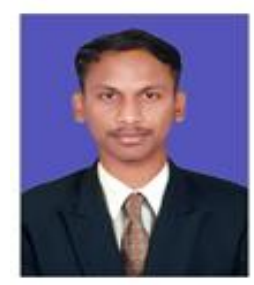

P. Mohamed Shameer received the B.E in Mechanical Engineering from National College of Engineering, Kovilpatti, and Tamil Nadu, India in 2013 and he is pursuing M.E in Thermal Engineering in Government College of Technology, Coimbatore, Tamil Nadu, India. 